Огляди літератури, оригінальні дослідження, погляд на проблему, випадок з практики, короткі повідомлення УДК 612.015.1:611-61-02:616-005.1-06:616.137.8/.147.3-005.4/-007.271-085.275]-092.9

DOI 10.11603/1811-2471.2019.v.i4.10815

\title{
ДИНАМІКА АНТИОКСИДАНТНО-ПРООКСИДАНТНОГО БАЛАНСУ КІРКОВОГО І МОЗКОВОГО ШАРІВ НИРКИ ПІСЛЯ ГОСТРОЇ КРОВОВТРАТИ, УСКЛАДНЕНОӦ ІШЕМІЄЮ-РЕПЕРФУЗІЄЮ КІНЦІВКИ, ТА ЙОГО КОРЕКЦІЯ КАРБАЦЕТАМОМ
}

\author{
๑В. В. Шацький, А. А. Гудима, Л. Я. Федонюк \\ Тернопільський національний медичний університет імені І. Я. Горбачевського МОЗ України
}

\begin{abstract}
РЕЗюМЕ. Мета роботи - з'ясувати вплив гострої крововтрати, ускладненої двогодинною ішемією кінцівки та її реперфузією, на антиоксидантно-прооксидантний баланс у кірковому і мозковому шарах нирки.

Матеріал і методи. Експерименти виконано на 108 нелінійних щурах-самцях масою 160-180 г. Усіх тварин поділили на чотири групи: контрольну та чотири дослідних (по 6 щурів у групі). До першої дослідної групи увійшли тварини, яким моделювали ішемію-реперфузію кінцівки. Під тіопентало-натрієвим знеболюванням тваринам проксимально на ліву лапку на 120 хв накладали джгут «SWAT-T» (CШA) шириною 10 мм, який повністю припиняв кровотік. У другій дослідній групі в умовах знеболювання тваринам моделювали гостру крововтрату в обсязі 2022 \% об'єму циркулюючої крові шляхом пересікання стегнової вени. У третій дослідній групі ці ушкодження поєднували. У четвертій дослідній групі тваринам з гострою крововтратою, ускладненою ішемією-реперфузією кінцівки, з метою корекції внутрішньоочеревинно вводили карбацетам в дозі 5 мг на кілограм маси тварини. Тварин виводили з експерименту під тіопентало-натрієвим знеболюванням через 3 і 4 години, а також через $1,7 \mathrm{i}$ 14 діб з моменту реперфузії, гострої крововтрати та їх поєднання, попередньо провівши визначення функціонального стану нирок методом стимульованого діурезу. В контрольній групі тварин вводили в наркоз, застосовуючи еквівалентну дозу тіопенталу натрію, накладали джгут без припинення кровотоку на 4 год, в подальшому через 3 год визначали функціональний стан нирок методом стимульованого діурезу, а далі під тіопентало-натрієвим знеболюванням тварин виводили з експерименту аналогічним методом. У гомогенатах кіркового і мозкового шарів видаленої нирки визначали вміст реагентів до тіобарбітурової кислоти і активність каталази. На основі цих даних розраховували антиоксидантно-прооксидантний індекс (АПІ).
\end{abstract}

Результати. Моделювання ішемії-реперфузії кінцівки у досліджуваних функціональних шарах нирки впродовж експерименту зумовлювало істотне зростання величини АПІ з максимумом через 1 добу, що вказувало на домінування антиоксидантних механізмів у тканинах нирки. Під впливом гострої крововтрати величина АПІ у кірковому та мозковому шарах нирки різко зменшувалася, досягаючи мінімуму через 1 добу, й не поверталася до рівня контролю через 14 діб. Ми вперше встановили, що моделювання гострої крововтрати та ішемії-реперфузії кінцівки зумовлювало ще більше зниження величини АПІ у функціональних шарах нирки. Якщо у кірковому шарі за цих умов показник ставав статистично вірогідно меншим, порівняно з групою з гострою крововтратою через 3 і 4 год та 14 діб спостереження, то у мозковому шарі додаткова ішемія-реперфузія супроводжувалася істотним зниженням величини АПІ у всі терміни реперфузійного періоду.

Застосування карбацетаму в дозі 5 мг на кілограм маси впродовж 14 діб рерфузійного періоду у тварин 3 гострою крововтратою, ускладненою ішемією-реперфузією, порівняно з тваринами без корекції, супроводжувалося істотним зростанням величини АПІ, починаючи з 7 доби - у мозковому шарі нирки, а через 14 діб - і в мозковому, і в кірковому шарах. Отриманий результат свідчить про перспективність карбацетаму як засобу системної корекції за умов гострої крововтрати, ускладненої ішемією-реперфузією кінцівки, і $\epsilon$ теоретичним підґрунтям для його використання у клініці.

Висновки. Внаслідок двогодинної ішемії та реперфузії кінцівки у досліджуваних функціональних шарах нирки істотно зростає величина АПІ з максимумом через 1 добу реперфузійного періоду, яка до 14 доби не досягає рівня контрольної групи. Під впливом гострої крововтрати величина АПІ у тканинах нирки різко зменшується, що свідчить про значне домінування прооксидантних механізмів, зумовлене зниженням перфузії нирки. Ускладнення гострої крововтрати ішемією-реперфузією кінцівки зумовлює статистично вірогідно більше зниження величини АПІ у кірковому шарі нирки, порівняно з групою з гострою крововтратою через 3 і 4 год та 14 діб спостереження, у мозковому шарі - у всі терміни реперфузійного періоду.

Використання впродовж 14 діб реперфузійного періоду карбацетаму в тварин з гострою крововтратою, ускладненою ішемією-реперфузією кінцівки, порівняно з тваринами без корекції, зумовлює істотне зростання величини АПІ, починаючи з 7 доби - у мозковому шарі нирки, а через 14 діб - і в мозковому, і в кірковому.

КлючовІ СлОВА: крововтрата; ішемія-реперфузія кінцівки; антиоксидантно-прооксидантний баланс.

Вступ. Останніми роками значно зросла частота терористичних атак та військових конфліктів. Згідно з даними дослідження Global terrorism Index, тероризм стає дедалі кривавішим: у 2014 році загальна кількість жертв терористичних атак збільшилася на 80 \% [13].
Основними причинами загибелі людей внаслідок терористичних атак чи під час бойових дій у 80-90 \% випадків стали масивна крововтрата та шок [15]. Найефективнішим засобом зупинки масивної зовнішньої кровотечі визнано накладання джгута, який повністю припиняє артеріальний 
Огляди літератури, оригінальні дослідження, погляд на проблему, випадок з практики, короткі повідомлення кровотік [14]. При масивній зовнішній кровотечі й, особливо, в умовах ведення бойових дій, джгут накладається проксимально на кінцівку. Вважають, що безпечний термін накладання - до двох годин.

Аналіз літератури показав, що накладання артеріального джгута навіть протягом «безпечного» терміну здатне викликати ускладнення. За даними [12], до найпоширеніших ускладнень належать ампутація кінцівки, пошкодження нервів і судин під джгутом, міонекроз, компартмент-синдром кінцівки з потребою фасціотомії, рабдоміоліз з розвитком гострої ниркової недостатності, тромбоз глибоких вен і легеневої артерії, пошкодження шкіри під джгутом з розвитком абсцесу.

У роботах окремих авторів зазначено, що реперфузія ішемізованої кінцівки після зняття джгута та відновлення кровотоку викликає запалення індукованих пошкодженням локальних ділянок. Медіатори запалення та токсичні метаболіти, потрапляючи в системний кровотік, можуть негативно впливати на життєво важливі органи [24, 25]. Констатується, що реперфузійне пошкодження органів і тканин можливе вже через 60 хв після локальної ішемії [18]

Одним із провідних механізмів пошкодження після ішемії/реперфузії $\epsilon$ гіперпродукція активних форм кисню (АФК). Надходження кисню до тканин після ішемії призводить до активації електронтранспортного ланцюга в мітохондріях і неконтрольованої продукції електронів, що супроводжується одноелектронним відновленням молекули кисню з утворенням супероксиданіона-радикалу [20]. Ще одним джерелом АФК $\epsilon$ активовані внаслідок контакту з ішемізованими тканинами нейтрофіли і макрофаги [19]. Ці процеси посилюються за умов гіпоксії, зумовленої крововтратою.

АФК ініціюють пероксидне окиснення поліненасичених жирних кислот і при надмірній кількості сприяють пошкодженню клітинних мембран [7]. В умовах недостатності антиоксидантного захисту відмічається виражене пошкодження клітинних мембран внаслідок пероксидації їх ліпідного біошару.

У науковій літературі існує велика кількість досліджень системних порушень в організмі як при масивній крововтраті, так і при використанні джгутів, як у цивільних [16], так і в бойових умовах [21]. Проте практично невивченим залишається системний вплив гострої крововтрати, ускладненої ішемією-реперфузією кінцівки, на нирки, які $\epsilon$ одними із основних органів-мішеней патогенного впливу гострої гіпоксії та ішемії-реперфузії [17, 22].

Мета - з'ясувати вплив гострої крововтрати, ускладненої двогодинною ішемією кінцівки та дантний баланс у кірковому і мозковому шарах нирки.

Матеріал і методи дослідження. Експерименти виконано на 108 нелінійних щурах-самцях масою 160-180 г з дотриманням правил «Європейської конвенції з захисту хребетних тварин, яких використовують з експериментальною та іншою науковою метою» (European Convention, 1984).

Усіх тварин поділили на чотири групи: контрольну та чотири дослідних (по 6 щурів у групі). До першої дослідної групи увійшли тварини, яким моделювали ішемію-реперфузію кінцівки. Під тіопентало-натрієвим знеболюванням (40 мг·кг ${ }^{-1}$ маси тіла) тваринами проксимально на ліву лапку накладали джгут на 120 хв. Застосовували смужку еластичного джгута «SWAT-T» (США) шириною 10 мм, що відповідає ширині джгута при накладанні на стегно дорослій людині. Такий джгут характеризується мінімальним негативним впливом на підлеглі тканини за рахунок своєї ширини і тривалим в часі больовим порогом [23]. Джгут затягували відповідно до нанесеного на ньому індикатора ефективного тиску, який припиняє кровотік, що додатково було підтверджено реографічним методом. У другій дослідній групі в умовах знеболювання тваринам моделювали гостру крововтрату шляхом пересікання стегнової вени. Після досягнення обсягу крововтрати 20-22 \% об'єму циркулюючої крові тваринам забезпечували гемостаз. У третій дослідній групі ці ушкодження поєднували. У четвертій дослідній групі тваринам з гострою крововтратою, ускладненою ішемією-реперфузією кінцівки, з метою корекції внутрішньоочеревинно вводили карбацетам (lнститут фізико-органічної хімії та вуглехімії НАН України, Донецьк) в дозі 5 мг на кілограм маси тварини [4]. Усім тваринам через 3 і 4 години, а також через 1, 7 і 14 діб після реперфузії, крововтрати чи їх поєднання, визначали функціональний стан нирок методом водного навантаження (збір сечі тривав 4 год), а далі під тіопентало-натрієвим знеболюванням тварин виводили з експерименту методом тотального кровопускання з серця.

Тварин контрольної групи вводили в наркоз застосовуючи еквівалентну дозу тіопенталу натрію, накладали джгут без припинення кровотоку на 4 год, у подальшому через 3 год визначали функціональний стан нирок методом водного навантаження, а далі під тіопентало-натрієвим знеболюванням тварин виводили з експерименту аналогічним методом.

Видалену нирку розміщували на льодяному столику і механічно виділяли кірковий і мозковий шари, в гомогенатах яких визначали вміст 
Огляди літератури, оригінальні дослідження, погляд на проблему, випадок з практики, короткі повідомлення реагентів до тіобарбітурової кислоти (ТБК-активних продуктів ПОЛ) - одного із основних скринінгових показників ліпідної пероксидації [2], i активність каталази - ключового компонента ферментативної ланки антиоксидантного захисту [6]. На основі цих даних розраховували антиоксидантно-прооксидантний індекс (АПІ = активність каталази / вміст ТБК-активних продуктів ПОЛ) [3]. Він належить до чутливих індикаторів стану антиоксидантного захисту та відображає баланс між антиоксидантними і прооксидантними механізмами.

Вірогідність відмінностей між контрольною і дослідними групами оцінювали з використанням непараметричного критерію Манна-Уїтні. Відмінності вважали істинними при вірогідності нульової гіпотези менше 5 \% $(p<0,05)$.

Результати й обговорення. Як видно з даних, наведених у таблиці 1, величина АПІ кіркового шару нирок під впливом ішемії-реперфузії кінцівки до 1 доби після зняття джгута підвищувалася, й у цей термін на 78,0 \% перевищувала рівень контролю $(p<0,05)$. В подальшому показник знижувався, проте до 14 доби залишався на 40,1 \% більшим, порівняно з контролем $(p<0,05)$. Після гострої крововтрати величина АПІ, навпаки, знижувалася, порівняно з контролем, досягаючи мінімального рівня через 1 добу (на 77,7 \%, р<0,05). До 14 доби показник зростав, проте залишався статистично вірогідно меншим, ніж у контролі (на $54,0 \%$, р<0,05). У всі терміни реперфузійного періоду величина АПІ на тлі гострої крововтрати була статистично вірогідно меншою, ніж після самої ішемії-реперфузії $\left(p_{1-2}<0,05\right)$.

Таблиця 1. Величина АПІ кіркового шару нирки (ум. од.) після гострої крововтрати, ускладненої ішемієюреперфузією кінцівки ((Mе (LQ; UQ) - медіана (нижній і верхній квартилі))

\begin{tabular}{|c|c|c|c|c|c|}
\hline \multirow{2}{*}{ Дослідна група } & \multicolumn{5}{|c|}{ Термін реперфузійного періоду } \\
\hline & 3 год & 4 год & 1 доба & 7 доба & 14 доба \\
\hline \multicolumn{6}{|c|}{ Контроль $=0,486(0,428 ; 0,541)(n=6)$} \\
\hline $\begin{array}{l}\text { Група } 1 \\
\text { Ішемія-реперфузія }\end{array}$ & $\begin{array}{c}0,644^{*} \\
(0,572 ; 0,728) \\
(n=6)\end{array}$ & $\begin{array}{c}0,621^{*} \\
(0,585 ; 0,681) \\
(n=6)\end{array}$ & $\begin{array}{c}0,883^{*} \\
(0,840 ; 0,953) \\
(n=6)\end{array}$ & $\begin{array}{c}0,850 * \\
(0,750 ; 1,005) \\
(n=6)\end{array}$ & $\begin{array}{c}0,695^{*} \\
(0,649 ; 0,798) \\
(n=6)\end{array}$ \\
\hline $\begin{array}{l}\text { Група } 2 \\
\text { Крововтрата }\end{array}$ & $\begin{array}{c}0,319 * \\
(0,305 ; 0,345) \\
(n=6)\end{array}$ & $\begin{array}{c}0,183^{*} \\
(0,177 ; 0,210) \\
(n=6)\end{array}$ & $\begin{array}{c}0,111 * \\
(0,105 ; 0,114) \\
(n=6)\end{array}$ & $\begin{array}{c}0,147^{*} \\
(0,142 ; 0,158) \\
(n=6)\end{array}$ & $\begin{array}{c}0,228^{*} \\
(0,219 ; 0,245) \\
(n=6)\end{array}$ \\
\hline $\begin{array}{l}\text { Група } 3 \\
\text { Ішемія- } \\
\text { реперфузія+ } \\
\text { крововтрата }\end{array}$ & $\begin{array}{c}0,166^{*} \\
(0,165 ; 0,166) \\
(n=6)\end{array}$ & $\begin{array}{c}0,102 * \\
(0,115 ; 0,125) \\
(n=6)\end{array}$ & $\begin{array}{c}0,090 * \\
(0,079 ; 0,098) \\
(n=6)\end{array}$ & $\begin{array}{c}0,128^{*} \\
(0,121 ; 0,130) \\
(n=6)\end{array}$ & $\begin{array}{c}0,134^{*} \\
(0,131 ; 0,138) \\
(n=6)\end{array}$ \\
\hline$P_{1-2}$ & $<0,05$ & $<0,05$ & $<0,05$ & $<0,05$ & $<0,05$ \\
\hline$P_{1-3}$ & $<0,05$ & $<0,05$ & $<0,05$ & $<0,05$ & $<0,05$ \\
\hline$P_{2-3}$ & $<0,05$ & $<0,05$ & $>0,05$ & $>0,05$ & $<0,05$ \\
\hline
\end{tabular}

Примітка. Тут і в таблиці 2:

1. * - відмінності стосовно контрольної групи статистично вірогідні $(p<0,05)$;

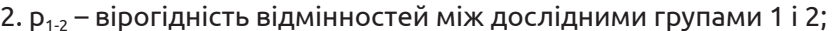

3. $\mathrm{p}_{1-3}$ - вірогідність відмінностей між дослідними групами 1 i 3;

4. р2-3 - вірогідність відмінностей між дослідними групами 2 і 3.

За умов гострої крововтрати, ускладненої ішемією-реперфузією, величина АПІ вже через 3 i 4 год реперфузійного періоду ставала статистично вірогідно меншою, ніж у групі з самою гострою крововтратою (відповідно на 48,0 \% і 44,3\%, $\left.\mathrm{P}_{2-3}<0,05\right)$. Через 1-7 діб показник між цими групами істотно не відрізнявся $\left(\mathrm{p}_{2-3}>0,05\right)$. Проте через 14 діб після самої крововтрати показник відновлювався швидше й на 70,1 \% перевищував аналогічний показник групи з гострою крововтратою, ускладненою ішемією-реперфузією $\left(\mathrm{p}_{2-3}<0,05\right)$.
У мозковому шарі нирок після двогодинної ішемії величина АПІ теж зростала, порівняно 3 контролем (табл. 2), проте ії максимум наставав через 7 діб реперфузійного періоду (у 2,28 раза, $\mathrm{p}<0,05)$. В усі терміни спостереження, за винятком 7 і 14 діб, цей показник у мозковому шарі нирки був статистично вірогідно меншим, ніж у кірковому: через 3 год - на 46,0 \%, через 4 год- на 15,0\%, через 1 добу - на 20,3\% (р<0,05). Після гострої крововтрати величина АПІ, навпаки, знижувалася, порівняно з контролем, досягаючи мінімуму че- 
Огляди літератури, оригінальні дослідження, погляд на проблему, випадок з практики, короткі повідомлення

Таблиця 2. Величина АПІ мозкового шару нирки (ум. од.) після гострої крововтрати, ускладненої ішемієюреперфузією кінцівки ((Me (LQ;UQ) - медіана (нижній і верхній квартилі))

\begin{tabular}{|c|c|c|c|c|c|}
\hline \multirow{2}{*}{ Дослідна група } & \multicolumn{5}{|c|}{ Термін реперфузійного періоду } \\
\hline & 3 год & 4 год & 1 доба & 7 доба & 14 доба \\
\hline \multicolumn{6}{|c|}{ Контроль $=0,347(0,329 ; 0,354)(n=6)$} \\
\hline $\begin{array}{l}\text { Група } 1 \\
\text { Ішемія-реперфузія }\end{array}$ & $\begin{array}{c}0,348 \\
(0,338 ; 0,386) \\
(n=6)\end{array}$ & $\begin{array}{c}0,528^{*} \\
(0,503 ; 0,548) \\
(n=6)\end{array}$ & $\begin{array}{c}0,704^{*} \\
(0,685 ; 0,762) \\
(n=6)\end{array}$ & $\begin{array}{c}0,765^{*} \\
(0,714 ; 0,896) \\
(n=6)\end{array}$ & $\begin{array}{c}0,617^{*} \\
(0,554 ; 0,672) \\
(n=6)\end{array}$ \\
\hline $\begin{array}{l}\text { Група } 2 \\
\text { Крововтрата }\end{array}$ & $\begin{array}{c}0,163^{*} \\
(0,160 ; 0,171) \\
(n=6)\end{array}$ & $\begin{array}{c}0,097^{*} \\
(0,095 ; 0,099) \\
(n=6)\end{array}$ & $\begin{array}{c}0,068 * \\
(0,066 ; 0,070) \\
(n=6)\end{array}$ & $\begin{array}{c}0,087^{*} \\
(0,082 ; 0,091) \\
(n=6)\end{array}$ & $\begin{array}{c}0,111^{*} \\
(0,108 ; 0,115) \\
(n=6)\end{array}$ \\
\hline $\begin{array}{l}\text { Група } 3 \\
\text { Ішемія-реперфузія+ } \\
\text { крововтрата }\end{array}$ & $\begin{array}{c}0,103 * \\
(0,100 ; 0,109) \\
(n=6)\end{array}$ & $\begin{array}{c}0,070 * \\
(0,062 ; 0,080) \\
(n=6)\end{array}$ & $\begin{array}{c}0,052 * \\
(0,048 ; 0,056) \\
(n=6)\end{array}$ & $\begin{array}{c}0,064^{*} \\
(0,060 ; 0,068) \\
(n=6)\end{array}$ & $\begin{array}{c}0,082^{*} \\
(0,079 ; 0,087) \\
(n=6)\end{array}$ \\
\hline$P_{1-2}$ & $<0,05$ & $<0,05$ & $<0,05$ & $<0,05$ & $<0,05$ \\
\hline$P_{1-3}$ & $<0,05$ & $<0,05$ & $<0,05$ & $<0,05$ & $<0,05$ \\
\hline$P_{2-3}$ & $<0,05$ & $<0,05$ & $<0,05$ & $<0,05$ & $<0,05$ \\
\hline
\end{tabular}

рез 1 добу з наступним зростанням до 14 доби. В усі терміни показник, порівняно з контролем та групою з ішемією-реперфузією (табл. 2), був статистично вірогідно меншим, ніж у контролі ( $\left.<<0,05, p_{1-2}<05\right)$. Привертає увагу факт, що на тлі крововтрати у мозковому шарі нирки величина АПІ у всі терміни реперфузійного періоду виявилася статистично вірогідно меншою, ніж у кірковому: через 3 год - на 48,9\%, через 4 год - на $47,0 \%$, через 1 добу - на 38,7\%, через 7 діб - на 40,8 \%, через 14 діб - на 51,3\% (р<0,05).

Ускладнення гострої крововтрати ішемією-реперфузією в мозковому шарі нирки зумовлювало статистично вірогідно меншу величину АПІ, порівняно з дослідною групою, в якій моделювали саму гостру крововтрату: через 3 год - на 36,8 \%, через 4 год - на 27,8 \%, через 1 добу - на 23,5 \%, через 7 діб - на 26,4 \%, через 14 діб - на 26,1\% ( $\left.p_{2-3}<0,05\right)$. За умов гострої крововтрати, ускладненої ішемією-реперфузією, величина АПІ в мозковому шарі нирки виявилася статистично вірогідно меншою, порівняно з кірковим, в усі терміни спостереження: через 3 год - на 38,0\%, через 4 год - на $39,1 \%$, через 1 добу - на 42,2 \%, через 7 діб - на $50,0 \%$, через 14 діб - на 38,8\% ( $<<0,05)$.

Оцінюючи ефективність корекції виявлених порушень карбацетамом за умов гострої крововтрати, ускладненої ішемією-реперфузією кінцівки, ми встановили, що на тлі застосування препарату в кірковому шарі нирки (рис. 1) через 7 діб величина

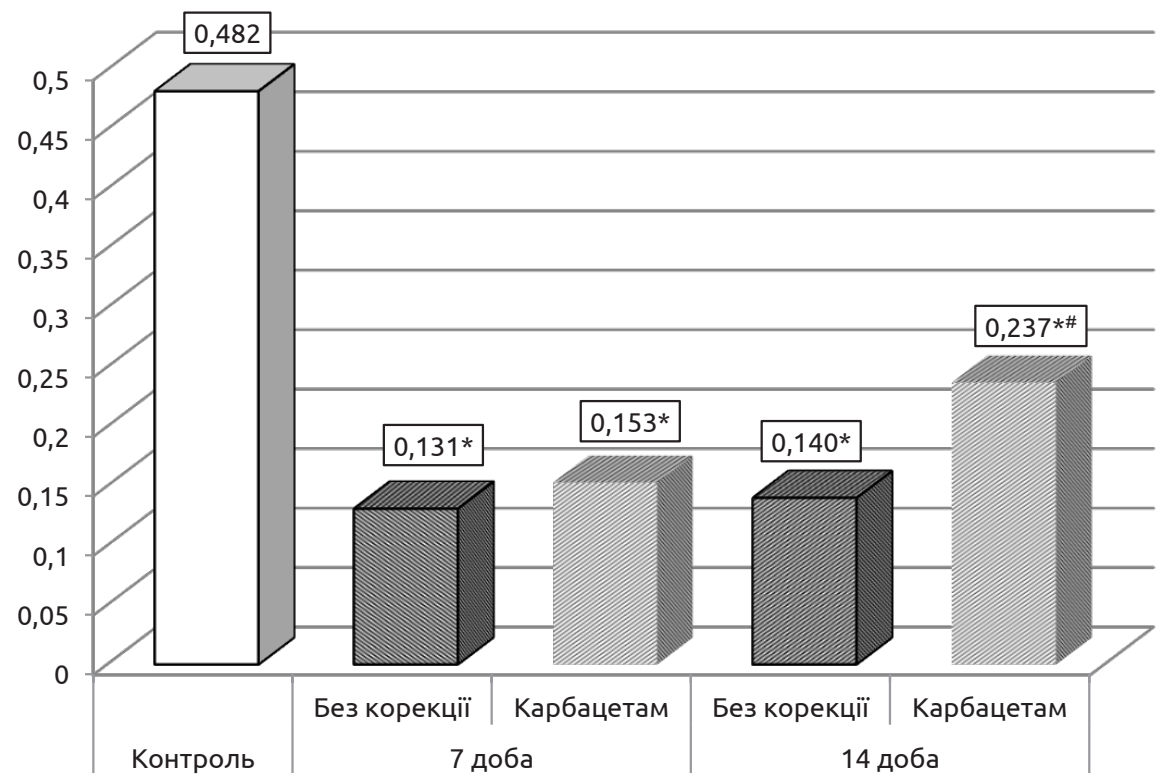

Примітка. Тут і на рисунку 2: * - відмінності стосовно контрольної групи статистично вірогідні, p<0,05; \# - відмінності стосовно групи без корекції статистично вірогідні, $p<0,05)$.

Рис. 1. Вплив карбацетаму на величину АПІ мозкового шару нирок (ум. од.) після гострої крововтрати, ускладненої ішемією-реперфузією кінцівки. 
Огляди літератури, оригінальні дослідження, погляд на проблему, випадок з практики, короткі повідомлення АПІ зростала, проте статистично вірогідно не відрізнялася від групи, в якій препарат не використовували ( $>0,05)$. Проте через 14 діб ефективність препарату була очевидною: у групі тварин з корекцією величина АПІ виявилася на 76,1 \% більшою, порівняно з тваринами без корекції $(p<0,05)$.

В мозковому шарі застосування карбацетаму супроводжувалося позитивним ефектом вже через 7 діб після реперфузії і його застосування (рис. 2). У тварин з корекцією величина АПІ в цей термін ставала на 62,5 \% більшою $(p<0,05)$. Аналогічною виявилася дія препарату й через 14 діб. Величина АПІ у групі тварин з корекцією перевищувала аналогічний показник тварин без корекції на 97,6\% ( $<<0,05)$.

Отримані результати свідчать про те, що внаслідок ішемії-реперфузії кінцівки у досліджуваних функціональних шарах нирки істотно зростає

величина АПІ з максимумом через 1 добу, що вказує на посилене надходження в цей орган прооксидантних чинників і компенсаторне посилення антиоксидантних механізмів. Слід зауважити що до 14 доби показник не досягає рівня контрольної групи й залишається значно вищим. Подібні результати в реперфузійному періоді отримували й інші автори [5]. Вони зазначають, що сукупність ендотоксинів, зумовлених двогодинною ішемією кінцівки та її реперфузією, розбалансовують захисні системи організму й зумовлюють тривале в часі напруження адаптаційно-компесаторних механізмів, яке стихає до 14 доби. В окремих публікаціях зазначають, що джерелом прооксидантного вплив у є також м' язи, судини та нервові волокна, які безпосередньо стискалися джгутом впродовж двох годин, були ішемізованими та зазнали реперфузійного пошкодження [1].

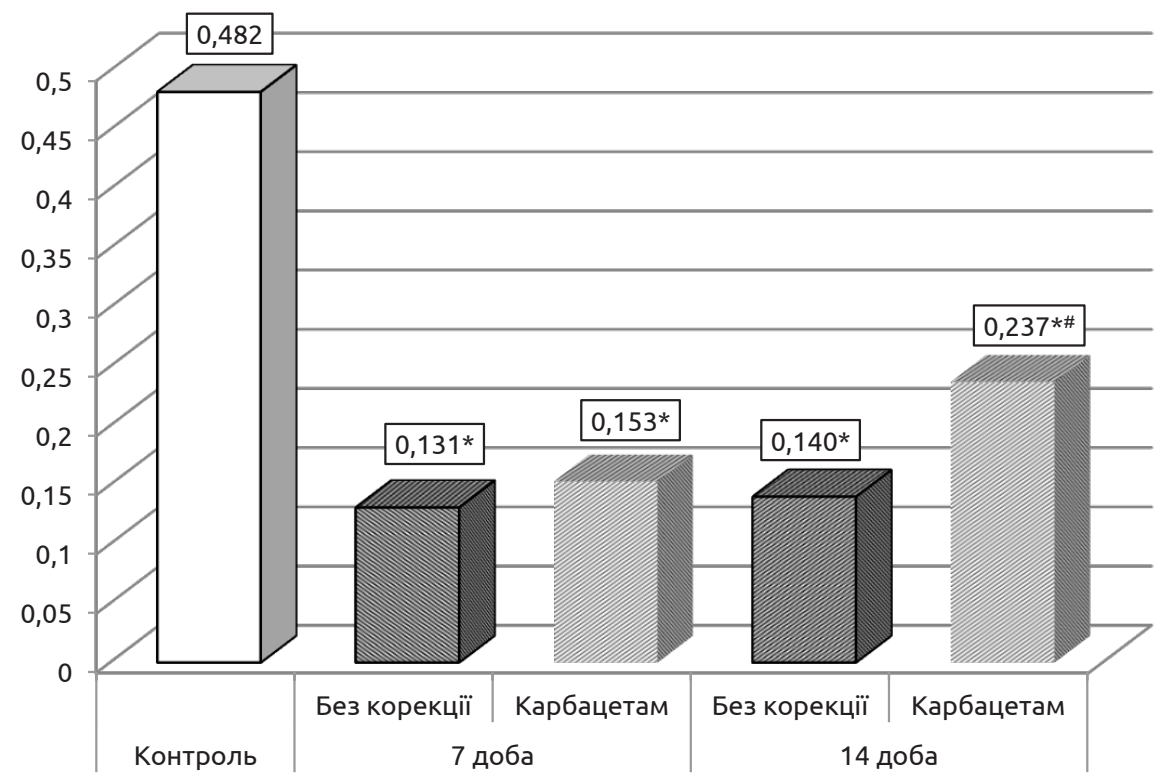

Рис. 2. Вплив карбацетаму на величину АПІ мозкового шару (ум. од.) нирок після гострої крововтрати, ускладненої ішемією-реперфузією кінцівки.

Під впливом гострої крововтрати величина АПІ у тканинах нирки різко зменшується, що свідчить про значне домінування прооксидантних механізмів, зумовлене зниженням перфузії нирки. Цей результат узгоджується з положенням про значну чутливість паренхіми нирок до гострої гіпоксії, оскільки фізіологічно нирка характеризується високими рівнями кровопостачання і споживання кисню. Маючи масу менше 1 \% від маси тіла, нирку перфузує близько 20 \% хвилинного об'єму крові. При цьому споживання кисню тканиною нирки становить близько 10 \% від поглинання кисню цілим організмом [10].

Ми вперше встановили, що моделювання гострої крововтрати та ішемії-реперфузії кінцівки зумовлює ще більше зниження величини АПІ функціональних шарів нирки. Якщо у кірковому шарі за цих умов показник стає статистично вірогідно меншим, ніж у групі з гострою крововтратою через 3 і 4 год та 14 діб спостереження, то у мозковому шарі додаткова ішемія-реперфузія супроводжується істотним зниженням величини АПІ у всі терміни реперфузійного періоду. Отриманий результат вказує на те, що вплив сукупності прооксидантних токсинів з ішемізованої впродовж двох годин кінцівки, чинить додатковий негативний вплив на паренхіму нирки з посиленням у ній процесів ліпопероксидації та виснаженням антиоксидантного захисту, що є одним з пускових механізмів системної відповіді організму на запа- 
Огляди літератури, оригінальні дослідження, погляд на проблему, випадок з практики, короткі повідомлення лення, яка, в свою чергу, значно збільшує ймовірність розвитку поліорганної недостатності. Аналогічний результат отримували й інші автори, які встановили, що двогодинна ішемія-реперфузія обох кінцівок суттєво поглиблює прояви поліорганної дисфункції внаслідок закритої травми живота, ускладненої крововтратою [11].

Крім цього, ми звернули увагу на той факт, що порушення АПІ у мозковому шарі нирки були більшими, що зумовлено вищою енергопродукцією мітохондрій канальцевого апарату нирки для забезпечення процесів активної реабсорбції електролітів.

Таким чином, накладання кровоспинного джгута, навіть впродовж безпечного періоду, викликає тривалі системні зміни в організмі та поглиблює сукупність порушень [26], зумовлених гострою крововтратою.

Для корекції виявлених порушень ми вперше випробували карбацетам, який за умов експериментальної скелетної травми, ускладненої крововтратою, чинить антиоксидантну, імуномоделювальну, детоксикаційну, мембраностабілізувальну і тканинопротекторну дію [4].

Дослідження показали, що використання впродовж 14 діб реперфузійного періоду карбацетаму, порівняно з тваринами без корекції, супроводжується істотним зростанням величини АПІ, починаючи з 7 доби - у мозковому шарі нирки, а через 14 діб - і в мозковому, і в кірковому шарах. Можна припустити, що в основі позитивної дії карбацетаму лежить його виражена антигіпоксійна активність, яка у 29-35 разів перевищує пірацетам [9]. Отриманий результат свідчить про перспективність карбацетаму як засобу системної корекції за умов гострої крововтрати, ускладненої ішемією-реперфузією кінцівки, і $\epsilon$ теоретичним підґрунтям для його використання у клініці.

\section{ЛІТЕРАТУРА}

1. Біохімічні зміни у сироватці крові щурів при ішемічно-реперфузійному синдромі (експериментальне дослідження) / А. А. Телев' як, Т. О. Вересюк, П. Р. Сельський, І. І. Боймиструк // Здобутки клінічної і експериментальної медицини. - 2018. - № 2 (34). - С. 122-128.

2. Доклінічні дослідження лікарських засобів : метод. рек.; за ред. О. В. Стефанова. - К. : Авіценна, 2001. 528 c.

3. Козак Д. В. Антиоксидантно-прооксидантний баланс тканини серця, легень і печінки в динаміці політравми / Д. В. Козак // Вісник Вінницького національного медичного університету. - 2014. - Т. 18, № 1. C. 17-20.

Висновки. 1. Унаслідок двогодинної ішемії та реперфузії кінцівки у досліджуваних функціональних шарах нирки істотно зростає величина АПІ, з максимумом через 1 добу реперфузійного періоду, яка до 14 доби не досягає рівня контрольної групи, що вказує на посилене надходження у нирку прооксидантних чинників і компенсаторне посилення антиоксидантних механізмів.

2. Під впливом гострої крововтрати величина АПІ у тканинах нирки різко зменшується, що свідчить про значне домінування прооксидантних механізмів, зумовлене зниженням перфузії нирки. Ускладнення гострої крововтрати ішемією-реперфузією кінцівки зумовлює ще більше зниження величини АПІ у функціональних шарах нирки. У кірковому шарі показник стає статистично вірогідно меншим від групи з гострою крововтратою через 3 і 4 год та 14 діб спостереження, а в мозковому шарі додаткова ішемія-реперфузія супроводжується істотним зниженням величини АПІ у всі терміни реперфузійного періоду.

3. Використання впродовж 14 діб реперфузійного періоду карбацетаму у тварин з гострою крововтратою, ускладненою ішемією-реперфузією кінцівки, порівняно з тваринами без корекції, зумовлює істотне зростання величини АПІ, починаючи з 7 доби - у мозковому шарі нирки, а через 14 діб - і в мозковому, і в кірковому шарах, що вказує на перспективність карбацетаму як засобу системної корекції за умов модельованої патології і $\epsilon$ теоретичним підґрунтям для його використання у клініці.

Перспективи подальших досліджень. У перспективі доцільно вивчити вплив ішемії-реперфузії на функціональний стан нирок у тварин 3 гострою крововтратою та ефективність за цих умов карбацетаму.

4. Козак Д. В. Вплив карбацетаму на антиоксидантний-прооксидантний баланс тканини серця, легень i печінки в динаміці політравми / Д. В. Козак // Шпитальна хірургія. - 2014. - № 1 (65). - С. 40-42.

5. Максимів Р. В. Динаміка балансу антиоксидантно-прооксидантних механізмів у внутрішніх органах під впливом артеріального джгута і реперфузії кінцівки / Р. В. Максимів, А. А. Гудима, В. М. Сидоренко // Шпитальна хірургія. Журнал імені Л. Я. Ковальчука. - 2017. № 1. - С. 37-44.

6. Метод определения активности каталазы / М. А. Королюк, Л. И. Иванова, И. Г. Майорова, В. Е. Токарев // Лабораторное дело. - 1988. - № 1. - С. 16-19. 
7. Нагорная Н. В. Оксидативный стресс: влияние на организм человека, методы оценки [электронный ресурс] / Н. В. Нагорная, Н. А. Четверик // Здоров'я дитини. - 2010. - № 2. - Режим доступа : http://www.mif-ua. com/archive/article/12762.

8. Постернак Г. И. Место кровоостанавливающего жгута в современном алгоритме временной остановки кровотечения на догоспитальном этапе / Г. И. Постернак, В. В. Лесной // Медицина неотложных состояний. 2017. - T. 4, № 83. - С. 57-60.

9. Семенов Н. С. Безопасная технология производства карбацетама - нового эффективного нейропротектора/Н.С. Семенов, М.В.Морозов, А.В. Кибальный// Охорона навколишнього середовища та раціональне використання природних ресурсів : V Міжнар. наук. конф. асп. і студ. Донецьк. - Донецьк : ДонНТУ, 2006. Т. 2. - С. 98-99.

10. Царенко С. В. Нейрореаниматология. Интенсивная терапия черепно-мозговой травмы / С. В. Царенко. - М. : Медицина, 2005. - 352 с.

11. Цимбалюк Г. Ю. Динаміка змін в антиоксидантно-прооксидантній системі в тканинах нирок при поєднаній травмі органів черевної порожнини на фоні гіповолемічного шоку та синдрому ішемії-реперфузії / Г. Ю. Цимбалюк // Шпитальна хірургія. Журнал імені л. Я. Ковальчука. - 2018. - Вип. 3 (38). - С. 63-69.

12. Clasper J. C. Limb complications following prehospital tourniquet use / J. C. Clasper, K. V. Brown, P. Hill // J. R. Army. Med. Corps. - 2009. - Vol. 155 (3). - P. 200-202.

13. Global Terrorism Index. - Access mode : http://economicsandpeace.org/wp-content/uploads/2015/11/2015Global-Terrorism-Index-Report.pdf.

14. Efficacy of prehospital application of tourniquets and hemostatic dressings to control traumatic external hemorrhage. - Access mode : https://www.ems.gov/pdf/ research/Studies-and-Reports.pdf.

15. Elster E. A. Implications of combat casualty care for mass casualty events / E. A. Elster, K. B. Frank, E. R. Todd // JAMA. - 2013. - Vol. 310 (5). - P. 475-476.

16. Development of personalized tourniquet systems using a new technique for measuring limb occlusion pressure : In World Congress on Medical Physics and Biomedical Engineering, (June 7-12, 2015) Toronto, Canada /
J. A. McEwen, B. A. Masri, B. Day, J. Jeyasurya. - Springer International Publishing, 2015. - P. 1325-1328.

17. Hydrogen sulphide and the kidney: important roles in renal physiology and pathogenesis and treatment of kidney injury and disease / I. Lobb, E. Sonke, G. Aboalsamh, A. Sener // Nitric Oxide. - 2015. - Vol. 46. - P. 55-65.

18. Lee C. Tourniquet use in the civilian prehospital setting / C. Lee K. M. Porter, T. J. Hodgetts // Emerg. Med. J. - 2007. - Vol. 24 (8). - P. 584-587.

19. Leukocytes and the inflammatory response in ischemiareperfusion injury / I. Francischetti, J. B. Moreno, M. Scholz, W. B. Yoshida // Rev. Bras. Cir. Cardiovasc. 2010. - Vol. 25 (4). - P. 575-584.

20. Murphy E. Mechanisms underlying acute protection from cardiac ischemia-reperfusion injury / E. Murphy, C. Steenbergen // Physiol. Rev. - 2008. - Vol. 88 (2). P. 581-609.

21. Point of injury tourniquet application during Operation Protective Edge-What do we learn? / A. Shlaifer, A. Yitzhak, E. N. Baruch [et al.] // J. Trauma Acute Care Surg. - 2017. - Vol. 83, No. 2. - P. 278-283.

22. Role of hydrogen sulfide in ischemia-reperfusion injury / D. Wu, J. Wang, H. Li [et al.] // Oxid. Med. Cell Longev. - 2015. - Vol. 1. - P. 1-16.

23. Tourniquets and occlusion: the pressure of design / P. L. Wall, D. C. Duevel, M. B. Hassan [et al.] // Mil. Med. - 2013. - Vol. 178 (5). - P. 578-587.

24. Van der Spuy L. Complications of the arterial tourniquet / L. Van der Spuy // South Afr. J. Anaesth. Analg. 2012. - Vol. 18 (1). - P. 14-18.

25. Wright G. Whould civilian pre-hospital emergency care provision include tourniquets for the management of uncontrolled traumatic haemorrhage? / G. Wright, V. S. Mcdonald, V. G. Smith // Australasian Journal of Paramedicine. - 2015. - Vol. 12 (4). - P. 1-5.

26. Volotovska N. V. Changes in the glutathione system's activity of internal organs in the first hours of experimental limb ischemia-reperfusion syndrome, combined with blood loss and mechanical injury / N. V. Volotovska, T. C. Nhokwara, I. V. Zhulkevych // Здобутки клінічної і експериментальної медицини. - 2019. - № 1. - С. 23-27. DOI 10.11603/1811-2471.2019.v0.i1.10043

\section{REFERENCES}

1. Televiak, A.T., Veresiuk, T.O., Selskyi, P.R., \& Boimystruk, I.I. (2018). Biokhimichni zminy u syrovatsi krovi shchuriv pry ishemichno-reperfuziinomu syndromi (eksperymentalne doslidzhennia) [Biochemical changes in blood serum of rats with reperfusion-ischemic syndrome (The experimental study)]. Zdobutky klinichnoi i eksperymentalnoi medytsyny - Achievements of Clinical and Experimental Medicine, 2 (34), 122-128 [in Ukrainian].

2.Stefanov, O.V.(Ed). (2001). Doklinichni doslidzhennia likarskykh zasobiv: metod. rek. [Preclinical drug research: guidelines]. Kyiv: Avitsenna [in Ukrainian].
3. Kozak, D.V. (2014). Antyoksydantno-prooksydantnyi balans tkanyny sertsia, lehen i pechinky v dynamitsi politravmy [Antioxidant-prooxidant balance of tissue of heart, lungs and liver in the dynamics of polytrauma]. Visnyk Vinnytskoho natsionalnoho medychnoho universytetu Bulletin of the Vinnytsia National Medical University, 18, 1, 17-20 [in Ukrainian].

4. Kozak, D.V. (2014). Vplyv karbatsetamu na antyoksydantnyi-prooksydantnyi balans tkanyny sertsia, lehen i pechinky $v$ dynamitsi politravmy [Effect of carbacetam on the antioxidant-prooxidant balance of tissue of the heart, 
Огляди літератури, оригінальні дослідження, погляд на проблему, випадок з практики, короткі повідомлення

lungs and liver in the dynamics of polytrauma]. Shpytalna khirurhiia - Hospital Surgery, 1 (65), 40-42 [in Ukrainian].

5. Maksymiv, R.V., Hudyma, A.A., \& Sydorenko, V.M. (2017). Dynamika balansu antyoksydantno-prooksydantnykh mekhanizmiv u vnutrishnikh orhanakh pid vplyvom arterialnoho dzhhuta i reperfuzii kintsivky [Dynamics of balance of antioxidant-prooxidant mechanisms in internal organs under the influence of arterial tourniquet and limb reperfusion]. Shpytalna khirurhiia. Zhurnal imeni L.Ya. Kovalchuka - Hospital Surgery. Journal named after L.Ya. Kovalchuk, 1, 37-44 [in Ukrainian].

6. Korolyuk, M.A., Ivanova, L.I., Mayorova, I.G., \& Tokarev, V.Ye. (1988). Metod opredeleniya aktivnosti katalazy [Method for determining the activity of catalase]. Laboratornoye delo - Laboratory Case, 1, 16-19 [in Russian].

7. Nagornaya, N.V., \& Chetverik, N.A. (2010). Oksidativnyy stress: vliyaniye na organizm cheloveka, metody otsenki [Oxidative stress: effect on the human body, assessment methods]. Zdorovia dytyny - Children's Health, 2. Retrieved from: http://www.mif-ua.com/archive/article/12762.

8. Posternak, G.I., \& Lesnoy, V.V. (2017). Mesto krovoostanavlivayushchego zhguta $v$ sovremennom algoritme vremennoy ostanovki krovotecheniya na dogospitalnom etape [The place of the hemostatic tourniquet in the modern algorithm for temporary stopping bleeding at the prehospital stage]. Meditsina neotlozhnykh sostoyaniy Emergency Medicine, 4, 83, 57-60 [in Russian].

9. Semenov, N.S., Morozov, M.V., \& Kibalnyi, A.V. (2006). Bezopasnaya tekhnologiya proizvodstva karbatsetama novogo effektivnogo neyroprotektora [Safe production technology of carbacetam - a new effective neuroprotective agent]. Proceedings of the $V$ International Scientific Conference graduate students and students: Okhorona navkolyshnoho seredovyshcha ta ratsionalne vykorystannia pryrodnykh resursiv - The Protection of the Environment and Rational Use of Natural Resources. Donetsk: DonNTU [in Russian].

10. Tsarenko, S.V. (2005). Neyroreanimatologiya. Intensivnaya terapiya cherepno-mozgovoy travmy [Neuroreanimatology. Intensive care for traumatic brain injury]. Moscow: Meditsina [in Russian].

11. Tsymbaliuk, H.Yu. (2018). Dynamika zmin v antyoksydantno-prooksydantnii systemi v tkanynakh nyrok pry poiednanii travmi orhaniv cherevnoi porozhnyny na foni hipovolemichnoho shoku ta syndromi ishemii-reperfuzii [Dynamics of changes in antioxidant-prooxidant system in kidney tissues with combined injury of abdominal organs on the background of hypovolemic shock and ischemiareperfusion syndrome]. Shpytalna khirurhiia. Zhurnal imeni L.Ya. Kovalchuka - Hospital Surgery. Journal named after L.Ya. Kovalchuk, 3 (38), 63-69 [in Ukrainian].

12. Clasper, J.C., Brown, K.V., \& Hill, P. (2009). Limb complications following pre-hospital tourniquet use. J. R. Army Med. Corps., 155 (3), 200-202.
13. Global Terrorism Index. Retrieved from: http://economicsandpeace.org/wp-content/uploads/2015/11/2015Global-Terrorism-Index-Report.pdf.

14. Efficacy of prehospital application of tourniquets and memostatic dressings to control traumatic external hemorrhage. Retrieved from: https://www.ems.gov/pdf/ research/Studies-and-Reports.pdf.

15. Elster, E.A., Frank, K.B., \& Todd, E.R. (2013). Implications of combat casualty care for mass casualty events. JAMA, 310 (5), 475-476.

16. McEwen, J.A., Masri, B.A., Day, B., \& Jeyasurya, J. (2015). Development of personalized tourniquet systems using a new technique for measuring limb occlusion pressure. World Congress on Medical Physics and Biomedical Engineering, (June 7-12, 2015) Toronto, Canada. Springer International Publishing, 1325-1328.

17. Lobb, I., Sonke, E., Aboalsamh, G., \& Sener, A. (2015). Hydrogen sulphide and the kidney: important roles in renal physiology and pathogenesis and treatment of kidney injury and disease, Nitric Oxide, 46, 55-65.

18. Lee, C., Porter, K.M., \& Hodgetts, T.J. (2007). Tourniquet use in the civilian prehospital setting. Emerg. Med. J., 24 (8), 584-587.

19. Francischetti, I., Moreno, J.B., Scholz, M., \& Yoshida, W.B. (2010). Leukocytes and the inflammatory response in ischemia reperfusion injury. Rev. Bras. Cir. Cardiovasc, 25 (4), 575-584

20. Murphy, E., \& Steenbergen, C. (2008). Mechanisms underlying acute protection from cardiac ischemia-reperfusion injury. Physiol. Rev., 88 (2), 581-609.

21. Shlaifer, A., Yitzhak, A., Baruch, E.N., Shina, A., Satanovsky, A., Shovali, A., ..., \& Glassberg, E. (2017). Point of injury tourniquet application during Operation Protective Edge-What do we learn? J. Trauma Acute Care Surg., 83, 2, 278-283.

22. Wu, D., Wang, J., Li, H., Xue, M., Ji, A., \& Li, Y. (2015). Role of hydrogen sulfide in ischemia-reperfusion injury. Oxid. Med. Cell Longev., 1, 1-16.

23. Wall, P.L., Duevel, D.C., Hassan, M.B., Welander, J.D., Sahr, S.M., \& Buising, C.M. (2013). Tourniquets and occlusion: the pressure of design. Mil. Med., 178 (5), 578-587.

24. Van der Spuy, L. (2012). Complications of the arterial tourniquet. South Afr. J. Anaesth Analg., 18 (1), 14-18.

25. Wright, G., Mcdonald, V.S., \& Smith, V.G. (2015). Whould civilian pre-hospital emergency care provision include tourniquets for the management of uncontrolled traumatic haemorrhage? Australasian Journal of Paramedicine, 12 (4), 1-5.

26. Volotovska, N.V., Nhokwara, T.C., \& Zhulkevych, I.V. (2019). Changes in the glutathione system's activity of internal organs in the first hours of experimental limb ischemia-reperfusion syndrome, combined with blood loss and mechanical injury. Zdobutky klinichnoi i eksperymentalnoi medytsyny-Achievements of Clinical and Experimental Medicine, 1, 23-27. DOI: 10.11603/1811-2471.2019.v0.i1.10043 
Огляди літератури, оригінальні дослідження, погляд на проблему, випадок з практики, короткі повідомлення ДИНАМИКА АНТИОКСИДАНТНО-ПРООКСИДАНТНОГО БАЛАНСА КОРКОВОГО
И МОЗГОВОГО СЛОЕВ ПОЧКИ ПОСЛЕ ОСТРОЙ КРОВОПОТЕРИ, ОСЛОЖНЕННОЙ
ИШЕМИЕЙ-РЕПЕРФУЗИЕЙ КОНЕЧНОСТИ, И ЕГО КОРРЕКЦИЯ КАРБАЦЕТАМОМ

\author{
๑В. В. Шацкий, А. А. Гудыма, Л. Я. Федонюк
}

Тернопольский национальный медицинский университет имени И. Я. Горбачевского МЗ Украины

РЕЗЮМЕ. Цель исследования - выяснить влияние острой кровопотери, осложненной двухчасовой ишемией конечности и ее реперфузией, на антиоксидантно-прооксидантный баланс в корковом и мозговом слоях почки.

Материал и методы. Эксперименты выполнены на 108 нелинейных крысах-самцах массой 160-180 г. Всех животных поделили на четыре группы: контрольную и четыре исследовательских (по 6 крыс в группе). В первую опытную группу вошли животные, которым моделировали ишемию-реперфузию конечности. Под тиопенталонатриевым наркозом животным проксимально на левую лапку на 120 мин накладывали жгут «SWAT-T» (CШA) шириной 10 мм, который полностью прекращал кровоток. Во второй опытной группе в условиях обезболивания животных моделировали острую кровопотерю в объеме 20-22 \% объема циркулирующей крови путем пересечения бедренной вены. В третьей опытной группе эти повреждения сочетали. В четвертой опытной группе животным с острой кровопотерей, осложненной ишемией-реперфузией конечности, с целью коррекции внутрибрюшинно вводили карбацетам в дозе 5 мг на килограмм массы животного. Животных выводили из эксперимента под тиопентало-натриевим обезболиванием через 3 и 4 часа, а также через 1, 7 и 14 суток с момента реперфузии, острой кровопотери и их сочетания, предварительно проведя определение функционального состояния почек методом стимулированного диуреза. В контрольной группе животных вводили в наркоз, применяя эквивалентную дозу тиопентала натрия, накладывали жгут без прекращения кровотока на 2 часа, в дальнейшем через 1 час определяли функциональное состояние почек методом стимулированного диуреза, а дальше под тиопенталонатриевим обезболиванием животных выводили из эксперимента аналогичным методом. В гомогенатах коркового и мозгового слоев удаленной почки определяли содержание реагентов тиобарбитуровой кислоты и активность каталазы. На основе этих данных рассчитывали антиоксидантно-прооксидантный индекс (АПИ).

Результаты. Моделирование ишемии-реперфузии конечности в исследуемых функциональных слоях почки в течение эксперимента приводило к существенному росту величины АПИ с максимумом через 1 сутки, что указывало на доминирование антиоксидантных механизмов в тканях почки. Под влиянием острой кровопотери величина АПИ в корковом и мозговом слоях почки резко уменьшалась, достигая минимума через 1 сутки, и не возвращалась к уровню контроля через 14 суток. Мы впервые установили, что моделирование острой кровопотери и ишемии-реперфузии конечности приводило к еще большему снижению величины АПИ в функциональных слоях почки. Если в корковом слое при этих условиях показатель становился достоверно меньшим, по сравнению с группой с острой кровопотерей через 3 и 4 часа и 14 суток наблюдения, то в мозговом слое дополнительная ишемия-реперфузия сопровождалась существенным снижением величины АПИ во все сроки реперфузионного периода.

Применение карбацетама в дозе 5 мг на килограмм массы в течение 14 суток реперфузионного периода у животных з острой кровопотерей, осложненной ишемией-реперфузией конечности, по сравнению с животными без коррекции, сопровождалось существенным ростом величины АПИ, начиная с 7 суток - в мозговом слое почки, а через 14 дней - и в мозговом, и в корковом слоях. Полученный результат свидетельствует о перспективности карбацетама как средства системной коррекции в условиях острой кровопотери, осложненной ишемиейреперфузией конечности, и является теоретическим основанием для его использования в клинике.

Выводы. Вследствие двухчасовой ишемии и реперфузии конечности в исследуемых функциональных слоях почки существенно возрастает величина АПИ с максимумом через 1 сутки реперфузионного периода, которая до 14 суток снижается, но не достигает уровня контрольной группы. Под влиянием острой кровопотери величина АПИ в тканях почки резко уменьшается, что свидетельствует о значительном доминировании прооксидантных механизмов и обусловлено снижением перфузии почки. Осложнения острой кровопотери ишемией-реперфузией конечности вызывает статистически достоверно большее снижение величины АПИ в корковом слое почки, по сравнению с группой с острой кровопотерей через 3, 4 часа, и 14 суток наблюдения, в мозговом слое - во все сроки реперфузионного периода.

Использование в течение 14 суток реперфузионного периода карбацетама у животных с острой кровопотерей, осложненной ишемией-реперфузией конечности, по сравнению с животными без коррекции, вызывает существенное увеличение величины АПИ, начиная с 7 суток - в мозговом слое почки, а через 14 суток - и в мозговом, и в корковом.

КЛЮЧЕВЫЕ СЛОВА: кровопотеря; ишемия-реперфузия конечности; антиоксидантно-прооксидантный баланс. 


\title{
Огляди літератури, оригінальні дослідження, погляд на проблему, випадок з практики, короткі повідомлення DYNAMICS OF ANTIOXIDANT-PROOXIDANT BALANCE OF RENAL CORTEX AND MEDULLA AFTER ACUTE BLOOD LOSS COMPLICATED BY ISCHEMIA-REPERFUSION OF THE EXTREMITY, AND ITS CORRECTION WITH CARBACETAM
}

\author{
oV. V. Shatsky, A. A. Gudyma, L. Ya. Fedoniuk

\section{Horbachevsky Ternopil National Medical University}

SUMMARY. The aim of the study - to find out the effect of acute blood loss, complicated by two-hour limb ischemia and its reperfusion, on the antioxidant-prooxidant balance in the renal cortex and medulla.

Material and Methods. The experiments were performed on 108 non-linear male rats weighing 160-180 g. All animals were divided into four groups: control and four research (6 rats per group). The first experimental group included animals that simulated limb ischemia-reperfusion. Under thiopental sodium anesthesia, animals were proximally placed on the left foot for 120 min with a $10 \mathrm{~mm}$ SWAT-T tourniquet (USA), which completely stopped the blood flow. In the second experimental group, in conditions of animal anesthesia, acute blood loss was simulated in the amount of 20-22 \% of the circulating blood volume by crossing the femoral vein. In the third experimental group, these injuries were combined. In the fourth experimental group, animals with acute hemorrhage complicated by limb ischemia-reperfusion were administered Carbacetam at a dose of $5 \mathrm{mg}$ per kilogram of the animal's weight with the aim of correction. Animals were withdrawn from the experiment under thiopental sodium anesthesia after 3 and 4 hours, as well as 1, 7 and 14 days after reperfusion, acute blood loss and their combination, after preliminary determination of the functional state of the kidneys by stimulated diuresis. In the control group, animals were injected anesthesia using an equivalent dose of thiopental sodium, a tourniquet was applied without stopping blood flow for 2 hours, then after 1 hour the functional state of the kidneys was determined by the method of stimulated diuresis, and then animals were removed from the experiment using thiopental sodium anesthesia by a similar method. In the removed kidney, the content of reagents in thiobarbituric acid and the activity of catalase were determined in the homogenates of the cortical and brain layers. Based on these data, the antioxidant-prooxidant index (API) was calculated.

Results. Modeling of limb ischemia-reperfusion in the studied functional layers of the kidney during the experiment led to a significant increase in the API value with a maximum after 1 day, which indicated the dominance of antioxidant mechanisms in the kidney tissues. Under the influence of acute blood loss, the IPA value in the cortical and brain layers of the kidney decreased sharply, reaching a minimum after 1 day and did not return to the control level after 14 days. We first established that the modeling of acute blood loss and limb ischemia-reperfusion led to an even greater decrease in the API value in the functional layers of the kidney. If in the cortical layer under these conditions the indicator became significantly lower compared with the group with acute blood loss after 3 and 4 hours, and 14 days of observation, then in the cerebral layer additional ischemia-reperfusion was accompanied by a significant decrease in the API value during all periods of the reperfusion period.

The use of Carbacetam at a dose of $5 \mathrm{mg}$ per kilogram of mass for 14 days in the reperfusion period in animals with acute blood loss complicated by limb ischemia-reperfusion compared with animals without correction was accompanied with a significant increase in API, starting from 7 days in the renal cortex, and after 14 days - both in the renal cortex and medulla. The obtained result indicates the future outlook of Carbacetam as a means of systemic correction in conditions of acute blood loss complicated by limb ischemia-reperfusion, and is the theoretical basis for its use in the clinic.

Conclusions. Due to two-hour ischemia and reperfusion of the limb in the studied functional layers of the kidney, the API increases significantly with a maximum after 1 day of the reperfusion period, which decreases to 14 days, but does not reach the level of the control group. Under the influence of acute blood loss, the IPA value in the kidney tissues decreases sharply, which indicates a significant dominance of prooxidant mechanisms and is due to a decrease in kidney perfusion. Complications of acute hemorrhage by ischemia-reperfusion of the limb cause a statistically significantly greater decrease in the API value in the cortical layer of the kidney compared with the group with acute blood loss after 3, 2 hours, and 14 days of observation, in the medulla during all periods of the reperfusion period.

The use of Carbacetam during 14 days of the reperfusion period in animals with acute blood loss complicated by limb ischemia-reperfusion, compared with animals without correction, causes a significant increase in the magnitude of API, starting from 7 days in the renal medulla, and after 14 days, both in the medulla and in the cortex.

KEY WORDS: blood loss; limb ischemia-reperfusion; anioxidant-prooxidant balance. 